\title{
An Analysis of Latino Male Immigrant Sex Offenders in Florida: The Impact of National Solutions on a Transnational Problem Alissa R. Ackerman* Rich Furman**
}

\begin{abstract}
This article assesses whether deported Latino immigrant sex offenders have similar offense types as each other (by country) and as deported non-Latino immigrants, and how they differ in terms of crimes committed and dispositions. To do so, the authors analyzed data available from the state of Florida, a state with one of the largest Latino populations in the United States. It situates the results of research within the current sociopolitical climate related to immigrants, fear of immigrants and sex offenders, and the nature of transnational migration.
\end{abstract}

Key words: sex offender, immigration, deportation.

\section{Resumen}

Este artículo evalúa si los latinos inmigrantes delincuentes sexuales deportados tienen el mismo tipo de delitos como los demás (por país) y como deportados no latinos inmigrantes, y cómo se diferencian en cuanto a los delitos cometidos y disposiciones. Para ello, los autores analizaron los datos disponibles en el estado de la Florida, uno de los estados con una de las mayores poblaciones de latinos en los Estados Unidos. Se sitúa a los resultados de la investigación en el actual clima socio-político en relación con los inmigrantes, el miedo de los inmigrantes y los delincuentes sexuales, y la naturaleza de la migración transnacional.

Palabras clave: delincuente sexual, inmigración, deportación.

\section{Introduction}

In the United States, two of the most stigmatized populations are undocumented immigrants and sexual offenders. Undocumented immigrants and other non-citizens that are convicted of sex crimes are undoubtedly

* Assistant Professor, Criminal Justice, Social Work Program, University of Washington, Tacoma. E-mail: ackerma1@u.washington.edu

** Professor, Social Work, University of Washington Tacoma. Email: rcfurman@u. washington.edu 
doubly stigmatized; discourse about them often renders them less than human (Ducat, Thomas \& Blood, 2009; Park \& Bhuyan, 2012). This discourse serves to isolate sex offenders; a potentially risky outcome, as research has demonstrated that community isolation and stress increase the likelihood of recidivism (Mercado, Alvarez \& Levenson, 2008).

The current national debate regarding immigration is often one based upon fear-fear of terrorism, fear of immigrants taking our job, and most recently, fear of the spread of violence and crime (Walker, Spohn \& Delone, 2011). This has been especially true over the last several years, as concerns that violence from the drug wars of Northern Mexico will begin to impact safety in the United States (Bradner, 2011). These fears have lead to perceptions about the prevalence of crime perpetrated by undocumented and documented immigrants that is often not supported by the evidence (Higgins, Gabbidon, Martin, 2010). As such, this article seeks to explore data to lend evidence to this important national and international discourse.

The purpose of this article is to assess whether deported Latino immigrant sex offenders, both undocumented and resident aliens, have similar offense types as each other (by country) and as deported non-Latino immigrants, and how they different in terms of crimes committed and dispositions. To do so, the authors analyzed data available from the state of Florida, a state with one of the largest Latino populations in the United States.

Prior to a description of the methodology and the analysis of the data, we shall situate the research within the current sociopolitical climate related to immigrants and sex offenders. While not all deported or deportable immigrant sex offenders are undocumented, the social perceptions of and dynamics concerning undocumented migrants provides an important social context that impacts how society deals with this population.

\section{Undocumented Immigration}

The United States has always had an ambivalent relationship to immigrants and immigration. While common mythology contends that we are 
a nation of immigration, and that we have always welcomed immigrants with open arms, this has not always been the case (Takaki, 1993). In fact, social perceptions regarding immigrants has largely been tied to where the state of the American economy is and our perceptions of the need for surplus labor (Delgado \& Covarrubias, 2008). For instance, in mid1800s Chinese immigrants were sought after to help build the transcontinental railroad, yet sentiments shifted during a severe economic downturn (Moran, 2005).

The same can be said of Mexican laborers during the early part of the twentieth century, when the Bracero worker program brought workers into the country, only to have the country turn against them at during another economic downturn.

The first decades of the twenty-first century mark a time of particular antipathy toward immigrants, in particular undocumented immigrants (Van Norstrand, 2011). The terrorist attacks of 9/11 and the subsequent American preoccupation with terrorism turned considerable American sentiment against most "others" (Sekhon, 2003). The "problem" of undocumented immigrants became increasingly viewed as evidence of the lack of security of the southern US border. If hundreds of thousand, and actually millions of undocumented Mexicans and Central Americans could easily enter the United States, then it would follow that terrorists could easily do the same (Tumlin, 2004). Thus, undocumented Latino immigrants began to be included in conversations about national security (Garcia, 2010). As undocumented immigrants have been often viewed as an "unknown other" with something of a mysterious, underworld quality, the connection between them and the potential of terror began to appear in public discourse (Johnson, 2010).

The phenomenon has intensified as the violence associated with Mexico's drug wars has escalated. The realization that Ciudad Juarez, situated just across the Texas border, is one of the most violent and dangerous city in the world has lead to concerns about violence from the drug wars spilling over into the United States (Bowden \& Briggs, 2010). The transnational nature of organized crime, as evidenced by the Maras gangs that migrated from Los Angeles to El Salvador, and now to other Central American countries, lends credence to this potential on the North American continent (Wolf, 2010). 


\section{Propaganda associated with immigration}

Propaganda in the media has slandered the image of immigrants, specifically attacking illegal immigrants committing sex crimes. Take for example Schurman-Kauflin (2006), generalizing illegal immigrants as those who "...use drugs and alcohol, are generally promiscuous, have little family stability..." (Schurman-Kauflin, 2006:3). In her analysis of illegal immigrant sex offenders, Schurman-Kauflin (2006) estimates that $2 \%$ of all illegal immigrants are sex offenders and extrapolates from this figure that 240,000 illegal sex offenders are in the United States. These findings contradict official numbers from the National Center for Missing and Exploited Children (2011) which estimates that there are approximately 740,000 registered sex offenders in the United States. While it is noted that many sex offenses never come to the attention of law enforcement, it is statistically extremely improbably that 240,000 illegal immigrant sex offenders are residing with in U.S. borders; this would make sex offenses rates for non documented immigrants nearly 33 percent, rates which are nearlly ten times the incidence found in any population.

Even among populations that are typically liberal and accepting of undocumented immigrants, there exist the perception that immigrants increase the rate of crime. For example, in one study of the attitude of social workers, a typically liberal population accepting of diversity, 30\% of respondents agreed or strongly agreed that undocumented immigration increases the rate of crime (Park, Bhuyan, Richards, \& Rundle, 2011). This is compared to $97 \%$ o of social workers in the sample that agreed or strongly agreed that undocumented immigrants were entitled to the same services access to social services. This indicates that even within populations that are possibly favorably predisposed to the welfare of undocumented immigrants, there exists a tendency to view them as being an increased threat for criminality.

\section{Sex Crimes, Immigration, and Victimization}

Sex crimes, especially those against children bring about a visceral response among members of the public. Just as fear and propaganda about 
illegal immigration foster myths about immigrants, so too are myths promulgated about sex offenders. As such, both have become pariahs. It becomes even more difficult to navigate the world when an individual is both an undocumented immigrant and a sexual offender.

The 2006 passage of the Adam Walsh Child Protection and Safety Act (AWA) included a stipulation that failure to register as a sex offender would result in deportation. Many offenses including sexual ones, are already deportable offenses under Act 237 of the Immigration and Nationality Act, but the AwA, adhering to public sentiment about sex offenders and immigrants goes one step further.

The current cultural zeitgeist regarding both sex offenders and immigrants may make it even more difficult for victims to come forward. For instance, research shows that the majority of offenses are committed by someone known to the victim (Berliner, Schram, Miller, \& Milloy, 1995) and in many cases the offender is a family member or close family friend. Even among U.S. citizens, many victims do not report sex crimes out of fear that their family will be disrupted and their loved one removed (Finklehor \& Wolak, 2003). These fears escalate with the potential for registration, community notification, and the long term consequences of both. These fears, in conjunction with the threat of deportation may decrease disclosure of abuse, especially among immigrant families. Given that sex crimes are deportable offenses, familial victims of immigrant offenders may be even less likely to report given the harsher consequence of deportation and their reliance on the abuser for financial support. As such, these victims do not obtain the supports available in the community. When immigrants do report sex crimes, it is possible that they are not investigated, as was the case in a Maricopa County Arizona suburb between 2005-2007 (Lacey, 2011). Sheriff Joe Arpaio from the Maricopa County Sheriff's Office in Arizona failed to investigate almost three dozen sex crimes reported in El Mirage, Arizona, where the Maricopa County Sheriff's office had contracted services. Many of these children were undocumented (Lacey, 2011).

In addition, immigrants are highly vulnerable and are disproportionally victimized in the work place. Given that undocumented immigrants are highly fearful of law enforcement and must keep their jobs for their survival, they are are often placed in situations that fall outside of the normal societal boundaries which inhibit sexual abuse. This is especially true 
for women migrant agricultural workers. This vulnerability and lack of propensity toward reporting is likely to be exacerbated by nativist immigration police which criminalize immigration itself (Johnson, 2009). For instance, in some states some law enforcement officers fear that restrictive immigration policies will lead to a decrease in reporting not only among non documented people, but throughout Latino communities (Aman \& Rehrig, 2011).

While issues of victimization and lack of investigation may disproportionately affect immigrants, it is possible that immigrant offenders in general, and Latino immigrants, specifically, are treated in disparate ways within the criminal justice system. The previous sections of this paper clearly point to the many issues surrounding sexual offending as it pertains to immigration and victimization; however, there is little to no research assessing the demographic characteristics of sex offenders who are being deported. This study is two fold. First, we assess whether there are differences between deported Latino and non-Latino offenders. Next, we determined the top five countries for deportation from Florida and assessed whether any significant differences existed between these deportees.

\section{Methodology}

This study explores sex crimes in Florida of Latino and non-Latino undocumented and alien residents deported for sex crimes. Florida was chosen for several reasons. First, it is a large state with a large Latino population, allowing for a sample size appropriate for analysis. Second, the state provides access to a public dataset that lists all registered sex offenders (RSO) regardless of their status in a Florida community (i.e. the list of offenders includes those that are incarcerated or civilly committed, living out of state, deported, and deceased, in addition to those living in Florida communities). Third, given the construction of Florida's public registry, the data accurately depict a large subset of deported sex offenders in the country.

The data for this study were obtained via an automated data-scraping program in the spring of 2010. The data were mapped to a relational database in Microsoft Access. One table contains offenders and their demographic profiles and the other list all offenses. The tables were con- 
nected via a unique offender identification number. The dataset included 55,725 offenders with 83,371 offenses. Data in the permanent address field allows the viewer to determine whether the offender is living within a Florida community, or is out of state, incarcerated, deported or deceased. For the purposes of this analysis, individuals who were listed as deported $(n=2,149)$ were separated into a second document.

Of the individuals deported, 1,404 had the country of deportation listed, and of those 944 were listed as being from Latin America. Forty-five countries had fewer than 5 Rsos deported to them. This amounted to 80 offenders, or $4.7 \%$ of the total from known countries. Mexico had 384 Rsos deported from Florida, which accounted for $22 \%$ of the known deportee's countries and $17.9 \%$ of the total number of deportees. Haiti, Nicaragua, Jamaica, and Honduras all had over 100 deported Rsos.

The state of Florida provides six racial categories: Asian, black, Indian, white, other, and unknown. As such, the state does not distinguish offenders of Hispanic or Latino decent. In fact, these individuals often have their race coded as white. To provide assurance that all Latino deportees were identified, the researchers recorded this data into two categories, Latino or not Latino. In order to recode this information, the researchers engaged in the following steps. First, we looked to see if the country of deportation was listed on the website. Second, when this information was not available, we reclassified the information by name of the RSO and checking the photograph of the RSO for confirmation and with their last name. When there was doubt in the mind of the researchers, they classified the case as unknown. While this method leave some room for error, the second author is bilingual and has worked with and published frequently on issues pertaining to Latinos. From these steps, it was determined that there were actually 1,370 Latino deportees, 5 of which for women, leaving 1,366 Latino men deported from the state of Florida.

\section{Comparison of Latino Deportees to Non-Latino Deportees}

The next phase of analysis was to determine differences between Latinos $(n=1365)$ and Non-Latino $(n=778)$ deportees. Latino deportees were slightly younger than non-Latinos. The average age for Latinos was 43.83 
(Range 20.25 - 85.8; $S D=11.95$ ), while for non-Latino the average age was 45.44 (Range 22.5 - 91.0; $S D=12.27$ ). Approximately $79 \%$ of those deported, both Latino and non-Latino, had victims that were minors. Latino deportees were responsible for 2,047 offenses, with an average of 1.46 (Range 1 - 10; SD = .87), whereas non-Latino deportees were responsible for 1,169 offenses with an average of 1.51 (Range $1-10$; $S D=.88$ ). ChiSquare Analysis was utilized to assess differences between Latino and nonLatino deportees on minor victims (yes/no) and predator status (offender/ predator). Similarly, t-tests were utilized to determine mean differences in number of offenses, number of counts, and age. No significant differences existed between Latino and non-Latino deportees.

\section{Comparison between countries of deportation}

The second analysis allowed us to determine differences, if any, between offenders from the five countries where offenders were deported to most often: Mexico, Haiti, Nicaragua, Jamaica, and Honduras (table 1).

Chi-square analysis was utilized to determine if any statistically significant differences were discernible with regard to the offender having a victim that was a minor $\left(\mathrm{X}^{2}(4)=11.392=.022\right)$. The chi square analysis yielded a significant result and standardized residuals show that the significant differences are found between deportees from Honduras and Nicaragua. These men are less likely to have victims that are minors. Over $30 \%$ of the men from Honduras and $21.9 \%$ of those from Nicaragua had adult victims, while Mexico, Haiti, and Jamaica all had fewer than $19 \%$ of their deportees with adult victims.

A second chi-square analysis was conducted to determine differences in offender status (offender/predator) among deportees $\left(\mathrm{x}^{2}(4)=15.983\right.$, $<.001)$. Offenders from Jamaica were statistically more likely to be listed as predators $(29.1 \%)$. Fewer than $20 \%$ of offenders from the other four countries had a predator status. Finally, chi-square analysis was used to assess differences in offense type $\left(\mathrm{x}^{2}(48)=93.976,<.001\right)$. Standardized residuals showed several statistically significant differences. Individuals from Mexico were statistically more likely to have their offense listed as "sexual battery on a child under 12. Almost 17\% (16.8\%) of Mexican deportees had 


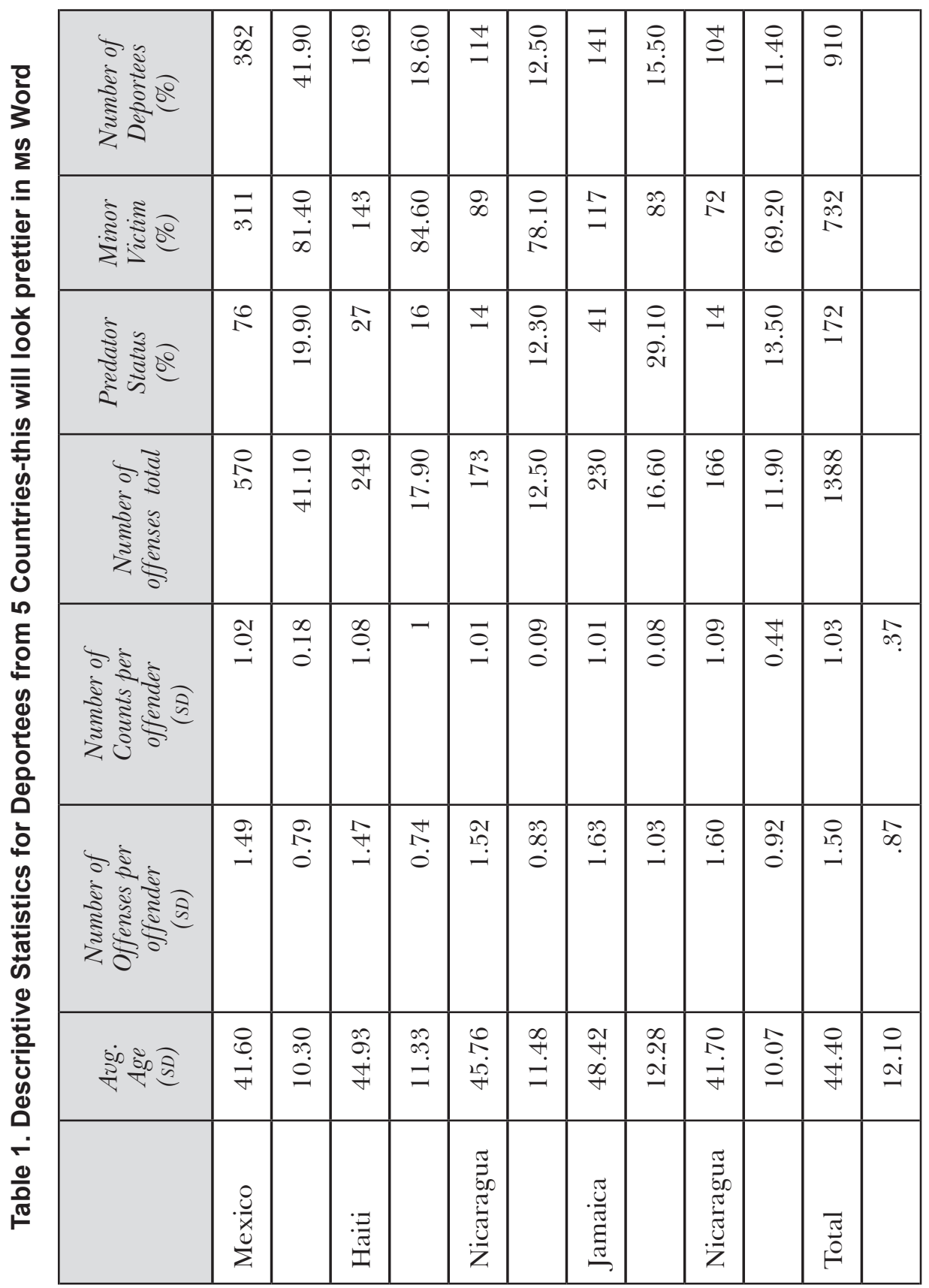


this offense listed, wheres less than $12 \%$ of deportees from other countries were listed for sexual battery on a child under 12. Deportees from Nicaragua were statistically more likely to have committed a "lewd assault or sexual battery on a 16 year old victim" and "lewd or lascivious exhibitionism on a victim under the age of 16 ". Almost $16 \%$ of Nicaraguan deportees $(15.8 \%)$ had committed a lewd or lascivious exhibitionist act compared to less than $6 \%$ of deportees from the other four countries. Approximately $8 \%$ had committed a lewd assault or sexual battery on a 16 year old, compared to less than $6 \%$ of deportees from the other 4 countries. Deportees from Jamaica had statistically more lewd assaults or sexual batteries on victims between the ages of 12 and 15 , but were less likely to use coercion to do so. More than $14 \%$ of Jamaican deportees had committed a lewd assault on a child between 12 and 15, compared to $10 \%$ or less for other deportees, but less than $1 \%$ utilized coercion to do so, compared with 2-5\% of other deportees. Finally, Honduran deportees were more likely to have committed a rape or sexual assault against an adult. Almost 12\% (11.5\%) had committed this crime compared to less than $6.5 \%$ for deportees from the other 4 countries.

Next, analysis of variance (ANOVA) was utilized to determine mean differences for age, number of offenses, and number of counts. Both age ( $\mathrm{F}$ $(4,905)=12.439,<.001)$ and number of offenses $(\mathrm{F}(4,905)=6.752$, $<.001)$ yielded statistically significant results. Bonferonni's post-hoc test was utilized to determine where mean differences could be found. With regard to age, mean differences can be seen between deportees from Mexico and those from Haiti, Nicaragua, and Jamaica. On average, Mexican deportees were significantly younger than deportees from these other three countries. Similarly, deportees from Jamaica were significantly older than those from Honduras. No differences were found for number of offenses or total number of counts.

\section{Discussion}

One implication for the findings is that the actual risks of sex offenders does not clearly match the public discourse regarding migration and security. For instance, Jamaican sex offenders were more likely in this sample 
to be predators than those from Latin American countries, yet current immigration discourse focuses on Latinos. The largest percentage of deportees were deported to Mexico, though the ones most likely to be listed as predators were from Jamaica. Future studies might do well to test significant predictors of deportation to determine whether country of origin or greatest risk posed influence decisions to deport.

Additionally, it could be presumed that those from Central American countries, given their history of youth gang violence and trauma, might have equally high rates of crimes against children then some of the other nations. This was not the case. What the data point to is the need for policy makers and practitioners to develop a nuanced understanding of the actual prevalence and nature of sex offences within immigrant communities, as these may differ cross culturally.

The nature of transnational migration and the likelihood that undocumented immigrants may easily reenter the country demands that we understand the actual offending patterns within these communities. The data shows that there were more Mexican immigrant sex offenders and offenses than individuals from other countries. Mexico and the United States share a common border, and therefore individuals can more easily reenter the country. This may be particularly true now, given that the Mexican judicial system is currently under significant stress as it struggles with controlling narcotrafficking and related violence. The ability to reenter the country and possibly re-offend remains high and without a proper understanding of culturally specific offending patterns, nothing is done to alleviate risk, both in the United States and abroad. A recent study speaks directly to this point. Hickman and Suttorp (2010) found that, in comparison to potentially deportable offenders who had not been deported, immigrants who had previously been deported and had criminal records were more likely to be rearrested, to be rearrested in less time, and to have more rearrests in a one year follow up. This could be because they are actually at higher risk for reoffending or are just more likely to come to the attention of law enforcement.

Along these lines, for those who argue that concerning ourselves with the social welfare of another country is beyond the scope of national policy should note that deportation will not make the United States inherently safer. The data shows that a good deal of the sample had committed seve- 
ral sexual crimes, demonstrating the need for transnationally oriented approaches to policy and practice, both to prevent sexually based offenses from occurring in the first place and to decrease rates of recidivism in the long run. Additionally, given that offenders are likely to offend when placed under extreme stress, are isolated, and have untreated psychosocial problems, merely deporting them may actually serve to increase the likelihood that if and when they do return to the US, they may re-offend. Similarly, research shows that after an offense, offenders experience collateral consequences of sex offender legislation and the stress, depression, hopelessness, isolation, and anger that may have led to the original offense may be exacerbated. This may be especially so for individuals who are deported and remains an area of research in need of exploration.

However, even if policy and practice is successful in keeping undocumented sex offenders from reentering the United States, the problems do not go away. We must begin to view sexual crimes committed by undocumented migrants in one country as a transnational criminal problem, in a similar way that we are starting to view the issue of transnational gangs. Viewing this problem transnationally will compel the reconsideration of criminal justice structures, policies and practices, and will lead to improved communication between criminal justice and treatment personnel in different countries. This type of transnational collaboration is rare; models most be developed that can help coordinate incarceration, community management, and treatment across nation state boundaries. One possibility is to engage in something similar to a transnational wrap around model advocated by Furman, Negi, Schatz \& Jones (2008). In this model, social problems are viewed as an opportunity for representatives from various systems to work transnationally on the level of individual cases and systems. Through the use of Internet and telephonic systems that are currently developed, such collaborations can occur inexpensively. However, the actual mechanisms for such work must be articulated; this would require a significant change in how systems collaborate transnationally.

Collateral consequences affect more than just the offender. The family of the sex offender also experiences the stress associated with sex offense legislation. Mistrust of law enforcement officials and the fear of deportation make it less likely for victims and other family members to 
come forward and report crimes. The consequences for this can be devastating. Such victims and family members are at increased risk of various psychosocial problems, such as depression, increased suicidality, and poor school performance. Creating a context that inhibits the reporting of such crimes makes expensive treatment more likely down the road, as preventative and early interventions are less likely to be initiated. Additionally, while it is true that most sex offenses are perpetrated against family members, all crimes are not. Communities therefore become less safe has families are more willing to hide sex offenders' behavior for fear of deportation. Deportation may serve to increase sexual offending both in countries of deportation and in the United States when offenders return. What is needed is evidenced-based social policy that takes into account the realities of recidivism and accounts for the nature of transnational migration.

\section{Conclusion}

In this article, we explore the social perceptions of and context of immigration in the United States, and explore how these have been factors that have influenced our treatment of Latino undocumented immigrants. These fears and perceptions, along with the manner in which sex offender policy has been created and is enforced has led to the frequent deportation of sex offenders in Florida. While on the surface this appears to be good social policy that may decrease the risk for communities in the United States, as with other aspects of sex offender policy, this may not be the case. The transnational nature of immigration means that many offenders can reenter the United States. Given the current sociopolitical situation in Mexico, which has been struggled with the creation of a sustainable and growing economy within the context of increased global competition and high levels of narcotrafficking violence, it is likely that deported sex offenders from this country may try to reenter the United States. By reentering the United States illegally, they will fail to register as sex offenders, and most certainly will not access treatment programs to help decrease their likelihood of re-offending. In addition, the inher- 
ently stressful and dehumanizing nature of illegal border crossings may increase their own victimization, another factor that may increase their likelihood of re-offending. Certainly, there are not simple answers to this complex problem. What is needed, however, is transnational collaboration between various institutions in the United States and those countries from where these undocumented offenders arrive and are deported to. Transnational problems will always resist simple resolution by one nation state.

\section{References}

Aman, A. C., \& Rehrig, G. (2011). The domestic face of globalization: Law's role in the integration of immigrants in the United States. Legal Studies Research Paper, \# 196, Indiana University School of Law. Bloomington, Indiana: University of Indiana.

Berliner, L., Schram, D., Miller, L., \& Milloy, C. D. (1995). A sentencing alternative for sex offenders: A study of decision making and recidivism. Journal of Interpersonal Violence, 10, 487-502.

Bowden, C., \& Briggs, A. L. (2010). Dreamland: the way out of Juarez. Austin, Texas. University of Texas Press.

Bradner, E. (2011, February 9). Immigration bill puts Indiana in Arizona camp. Evansville Courier \& Press. Retrieved December 12, 2011, from http://www. courierpress.com/news/2011/feb/09/immigration-bill-puts-indiana-inarizona-camp/

Delgado, R., \& Covarrubias, H. M. (2008). Capitalist restructuring, developing and labor migration: The Mexico-US case. Third World Quarterly, 29(7), 1359-1374.

Ducat, L., Thomas, S., \& Blood, W. (2009). Sensationalising sex offenders and sexual recidivism: Impact of the Serious Sex Offender Monitoring Act 2005 on media reportage. Australian, Psychologist, 44(3), 156-165.

Finkelhor, D., \& Wolak, J. (2003). Reporting assaults against juveniles to the police: Barriers and catalysts. Journal of Interpersonal Violence, 18, 103-128.

Furman, R. Negi, N. J., Schatz, M. C. S \& Jones, S. (2008). Transnational social work: Using a wrap-around model. Global Networks: A Journal of Transnational Affairs 8(4), 496-503.

Garcia, E. (2010). National security, unskilled labor, and why the United States should overhaul its immigration policy, South Texas Law Review, 4(51), 10431065 . 
Hickman, L.J. \& Suttorp, M.J. (2010). The recidivism patterns of previously deported aliens released from a local jail: Are they high-risk offenders? Crime and Delinquency, 56, 507-534.

Higgins, G. E., Gabbidon, S. L., Martin, F. (2010). The role of race/ethnicity and race relations on public opinion related to the immigration and crime link. Journal of Criminal Justice, 38(1), 51-56.

Johnson, K. R. (2009). The intersection of race and class in U.S. Immigration law and enforcement. Law and Contemporary Problems, 72, 4, 1-35.

- (2010). Its the economy stupid: The hijacking of the debate over immigration reform by monsters, ghosts and goblins (or, the war on drugs, war on terror, narcoterrorists, ect). UC Davis Legal Studies Research Paper No: 213. Chapman Law Symposium, 2010.

Lacey, M. (2011, Dec. 9). Arpaio Is Criticized Over Handling of Sex-Crimes Cases. The New York Times. Retrieved on January 5, 2012 from http://www.nytimes. com/201 1/12/10/us/sheriff-joe-arpaio-criticized-over-handling-of-sex-crimescases.html

Mercado, C. C., Alvarez, S., \& Levenson, J. (2008). The impact of specialized sex offender legislation on community reentry. Sexual Abuse: A Journal of Research and Treatments, 20(2), 188-205.

Moran, M. C. (2005). Coming to America: Immigration from 1840-1930. Pelham, New York: Benchmark Education.

National Center for Missing and Exploited Children, (2011). National Center for Missing and Exploited Children, Registered sex offenders in the United States. Retrieved January 13, 2012, from http://www.missingkids.com/en_US/documents/sexoffender-map.pdf.

Park, Y., \& Bhuyan, R. (2012). Whom should we serve? A discourse analysis of social workers' commentary on undocumented immigrants. Journal of Progressive Human Services, 23, 18-40.

Park, Y., Bhuyan, R., Richards, C., \& Rundle, A. (2011). U.S. social work practitioners' attitudes toward immigrants and immigration: Results from an online survey. Journal of Immigrant E Refugee Studies, 9, 367-392.

Schurman-Kauflin. D. (2006). "Profiling sex trafficking: Illegal immigrants at risk". Violent Crimes Institute, Bolletin num. 3, Violent Crimes Institute, National Bureau of Justice, Washington, DC.

Sekhon, V. (2003). The civil rights of "others": Anti-terrorism, the Patriot Act, and Arab and South Asian Americn rights in post-p/11 American Society. Texas Journal on Civil Liberties \& Civil Rights, 9(1), 117-148.

Takaki, R. (1993). A Different Mirror: A History of Multicultural America. NY: Little, Brown and Company.

Tumlin, K. C. (2004). Suspect first: How terrorism policy is reshaping immigration policy. California Law Review, 19(4), 1175-1240. 
Van Norstrand, C. J. H.(2011). Crossing with the virgin: Stories from the migrant trail. Human Rights Quarterly, 33(2), 552-563.

Walker, S., Spohn, C. \& Delone, M. (2011). The color of justice: Race, ethnicity and crime in America. Boston: Cengage.

Wolf, S. (2010). Maras transnacional: Origins and transformations of Central American street gangs. Latin American Research Review, 45(1), 256-265.

Artículo recibido el 27 de junio de 2012 Segunda versión aprobada el 10 de mayo de 2013 